\title{
Effect of a nutrient mixture on matrix metalloproteinase-9 dimers in various human cancer cell lines
}

\author{
M.W. ROOMI, T. KALINOVSKY, M. RATH and A. NIEDZWIECKI \\ Dr. Rath Research Institute, 1260 Memorex Drive, Santa Clara, CA 95050, USA
}

Received October 17, 2013; Accepted December 3, 2013

DOI: 10.3892/ijo.2013.2235

\begin{abstract}
Strong clinical and experimental evidence demonstrates association of elevated levels of matrix metalloproteinase MMP-9 with cancer progression, metastasis and shortened patient survival, as it plays a key role in tumor cell invasion and metastasis by digesting the basement membrane and ECM components. MMP-9 is secreted in both the monomeric and dimeric form. Although there is little research on MMP-9 dimers, some studies have shown the dimer to be associated with more aggressive tumor progression. Our objective was to study the relative secretion patterns of MMP-9 monomer and dimer in a variety of cancer cell lines and the effect of a nutrient mixture (NM) containing lysine, proline, ascorbic acid and green tea extract on MMP-9 secretion. The cancer cell lines were grown in their respective media, supplemented with $10 \%$ FBS, penicillin $(100 \mathrm{U} / \mathrm{ml})$ and streptomycin $(100 \mu \mathrm{g} / \mathrm{ml})$ in 24-well tissue culture plates. At near confluence, the cells were treated with NM at 0,10, 50, 100, 500 and $1000 \mu \mathrm{g} / \mathrm{ml}$. Parallel sets of cultures were treated with PMA $(100 \mathrm{ng} / \mathrm{ml})$ for induction of MMP-9. Cell MMP-9 secretion was assayed by gelatinase zymography. MMP-9 dimer secretion patterns of cancer cells fell into different categories. We observed no MMP-9 dimer in prostate DU-145 and PC-3, pancreatic MIA-Pa-Ca2, colon HCT-116, bladder T-24, head and neck FaDu, glioblastoma A-172, T-98 and LN-18 and leukemia HL-60, Jurkat, and Raji cell lines. MMP-dimer secretion only with PMA induction was seen in breast MCF-7 and MDA-MB-231, uterine SK-UT-1, lung A-549, tongue SC-25, melanoma A2058, osteosarcoma U-2OS, rhabdomyosarcoma, fibrosarcoma HT-1080, chondrosarcoma SW-1350 and liposarcoma SW-872. Cervical HeLa and DoTc 2 4510, renal 786-0 and HCC SK-Hep-1 cells exhibited MMP-9 dimer without PMA treatment and increased secretion with PMA treatment. Sarcomas had the highest levels of MMP-9 monomer and dimer with and without PMA among
\end{abstract}

Correspondence to: Dr Aleksandra Niedzwiecki, Dr. Rath Research Institute, 1260 Memorex Drive Santa Clara, CA 95050, USA

E-mail: author@drrath.com

Key words: MMP-9 dimers, nutrient mixture, human cancer cell lines these cancer cell lines. Cervical, uterine and male breast cancer cell lines showed the next highest levels of MMP-9, followed by breast cancer cell lines. Melanoma, renal, lung, head and neck and HCC showed lower levels and prostate, glioblastoma, bladder and leukemia cell lines the lowest. NM showed dosedependent inhibition of MMP-9 monomer and dimer in all cell lines tested. In conclusion, high MMP-9 and dimer secretion levels correlated with the most aggressive cancer cell lines. NM was effective in inhibiting MMP-9 and dimer secretion in all cell lines tested, suggesting its therapeutic potential as an antimetastatic agent.

\section{Introduction}

Strong clinical and experimental evidence demonstrates association of elevated levels of matrix metalloproteinase MMP-9, a type IV collagenase, with cancer progression, metastasis and shortened patient survival, as it plays a key role in tumor cell invasion and metastasis by digesting the basement membrane and ECM components (1-6). In addition to proteolysis, MMP-9 has been shown to play an important role in cell migration $(7,8)$. A unique characteristic of MMP-9 is the ability to be secreted in both the monomeric and a disulfidebonded dimeric form. Dufour et al reported that dimerization of MMP-9 through the hemopexin domain appears necessary for MMP-9 enhanced cell migration (7). By using mutagenesis and biochemical approaches it was demonstrated that the MMP-9 dimer (present usually as $10-15 \%$ of the MMP-9 population), not the monomer, is required for this functional activity of MMP-9 (7). For example, peptides interfering with MMP-9 dimerization abrogated MMP-9 enhanced cell migration in COS-1 (7).

Rath and Pauling (9) proposed using nutrients such as lysine and ascorbic acid to target plasmin-mediated connective tissue degradation as a universal approach to tumor growth and expansion. Binding to plasminogen active sites, lysine blocks plasminogen activation into plasmin by tissue plasminogen activator (t-PA). Thus, it modulates the plasmin-induced MMP activation cascade (10). Subsequent studies confirmed this approach and led to the identification of a novel formulation composed of lysine, ascorbic acid, proline and green tea extract and other micronutrients (NM), which has shown significant anticancer activity against a large number $(40)$ of cancer cell lines, blocking cancer growth, tissue invasion and MMP expression both in vitro and in vivo (11-13). 
In this study, our main objectives were to study the relative secretion patterns of MMP-9 monomer and dimer in a variety of carcinoma, sarcoma, adenosarcoma and leukemia cell lines and to evaluate the effect of the NM on MMP-9 monomer and dimer secretion by these cells.

\section{Materials and methods}

Materials. Thirty-eight different cancer cell lines were selected on the basis of organ malignancies and included carcinomas, sarcomas, adenosarcomas and leukemias. The cancer cell lines and their recommended media were purchased from ATCC (Manassas, VA, USA). Antibiotics, penicillin and fetal bovine serum (FBS), were obtained from Gibco (BRL, Long Island, NY,USA). Twenty-four-well tissue culture plates were obtained from Costar (Cambridge, MA, USA). Gelatinase zymography was performed in $10 \%$ Novex pre-cast SDS polyacrylamide gel (Invitrogen Corp.) with $0.1 \%$ gelatin in non-reducing conditions. The nutrient mixture (NM), prepared by VitaTech (Hayward, CA, USA) was composed of the following ingredients in the relative amounts indicated: Vitamin $\mathrm{C}$ (as ascorbic acid and as $\mathrm{Mg}$, Ca, and palmitate ascorbate) $700 \mathrm{mg}$; L-lysine $1000 \mathrm{mg}$; L-proline $750 \mathrm{mg}$; L-arginine $500 \mathrm{mg}$; N-acetyl cysteine $200 \mathrm{mg}$; standardized green tea extract ( $80 \%$ polyphenol) $1000 \mathrm{mg}$; selenium $30 \mu \mathrm{g}$; copper $2 \mathrm{mg}$; manganese $1 \mathrm{mg}$. All other reagents used were of high quality and were obtained from Sigma, unless otherwise indicated.

Cell cultures. The cancer cell lines were grown in their respective media, supplemented with $10 \% \mathrm{FBS}$, penicillin $(100 \mathrm{U} / \mathrm{ml})$, and streptomycin $(100 \mu \mathrm{g} / \mathrm{ml})$ in 24-well tissue culture plates. The cells were plated at a density of $1 \times 10^{5}$ cells $/ \mathrm{ml}$ and grown to confluency in a humidified atmosphere at $5 \% \mathrm{CO}_{2}$ at $37^{\circ} \mathrm{C}$. Serum-supplemented media were removed and the cell monolayer was washed once with PBS with the recommended serum-free media. The cells were treated with the nutrient mixture, dissolved in media and tested at 0,10, 50, 100, 500 and $1000 \mu \mathrm{g} / \mathrm{ml}$. Parallel sets of cultures were treated with PMA (100 ng/ml) for induction of MMP-9. Control and PMA treatments were done in triplicates. The plates were then returned to the incubator. The conditioned media were collected separately, pooled and centrifuged at $4^{\circ} \mathrm{C}$ for $10 \mathrm{~min}$ at $3000 \mathrm{rpm}$ to remove cells and cell debris. The supernatant was collected and used to assess for MMP-9 monomer and dimer by gelatinase zymography.

Gelatinase zymography. Gelatinase zymography was performed in $10 \%$ NOVEX Pre-Cast SDS polyacrylamide gel (Invitrogen Corp.) in the presence of $0.1 \%$ gelatin under nonreducing conditions. Culture media $(20 \mu \mathrm{l})$ were mixed with sample buffer and loaded for SDS-PAGE with Tris glycine SDS buffer as suggested by the manufacturer (Novex). Samples were not boiled before electrophoresis. Following electrophoresis the gels were washed twice in $2.5 \%$ Triton $\mathrm{X}-100$ for $30 \mathrm{~min}$ at room temperature to remove SDS. The gels were then incubated at $37^{\circ} \mathrm{C}$ overnight in substrate buffer containing $50 \mathrm{mM}$ Tris- $\mathrm{HCl}$ and $10 \mathrm{mM} \mathrm{CaCl}_{2}$ at $\mathrm{pH} 8.0$ and stained with $0.5 \%$ Coomassie Blue R250 in 50\% methanol and $10 \%$ glacial acetic acid for $30 \mathrm{~min}$ and destained. Upon renaturation of the enzyme, the gelatinases digest the gelatin in the gel and give clear bands against an intensely stained background. Protein standards were run concurrently and approximate molecular weights were determined by plotting the relative mobilities of known proteins.

Gelatinase zymograms were scanned using CanoScan 9950F Canon scanner at $300 \mathrm{dpi}$. The intensity of the bands was evaluated using the pixel-based densitometer program Un-Scan-It, version 5.1, 32-bit, by Silk Scientific Corp. (Orem, UT, USA), at a resolution of one scanner unit (1/100 of an inch for an image that was scanned at $100 \mathrm{dpi}$ ). The pixel densitometer calculates the optical density of each pixel (values, 0-255) using the darkly stained background of the gel as a pixel value of 0 . A logarithmic optical density scale was used since the optical density of the film and gels is logarithmically proportional to the concentration. The pixel densitometer sums the optical density of each pixel to give the band density.

\section{Results}

MMP-9 dimer secretion patterns of cancer cells fell into different categories, as shown in Table I. MMP-9 dimer secretion was not detected in prostate DU-145 and PC-3, testicular NTER-2, hepatocarcinoma Hep-G2, pancreatic MIA-Pa-Ca2, colon HCT-116, bladder T-24, head and neck $\mathrm{FaDu}$, uterine MES-SA and MES-SA/Dx5, neuroblastoma, synovial sarcoma SW-982, osteosarcoma MNNG, Ewings sarcoma SK-ES-1, glioblastoma A-172, T-98 and LN-18 and leukemia HL-60, Jurkat, and Raji cell lines. Cell lines, such as breast MCF-7 and MDA-MB-231, cervical HeLa, uterine SK-UT-1, lung A-549, tongue SC-25, melanoma A2058, osteosarcoma U-2OS, rhabdomyosarcoma, fibrosarcoma HT-1080, chondrosarcoma SW-1350 and liposarcoma SW-872 exhibited MMP-dimer secretion only with PMA induction. Cervical DoTc 2 4510, renal 786-0, breast Colo-824 and HCC SK-Hep-1 exhibited MMP-9 dimer without PMA treatment and increased secretion with PMA treatment. Zymograms and densitometry analyses of representative cell lines secreting MMP-9 dimers with and without PMA induction are discussed below.

Dimer secretion with PMA. Breast MCF-7 and MDA-MB-231, cervical HeLa, uterine SK-UT-1, lung A-549, tongue SC-25, melanoma A2058, osteosarcoma U-2OS, rhabdomyosarcoma, fibrosarcoma HT-1080, chondrosarcoma SW-1350 and liposarcoma SW-872 exhibited MMP-dimer secretion only with PMA induction. See Table I for relative secretion of MMP-9 monomer and dimer. Zymograms and densitometry analyses of secretion patterns of MMP-9 monomer and dimer of the representative cancer cell lines breast, MCF-7, lung A-549, osteosarcoma U-2OS and chondrosarcoma SW1353 are presented below.

Breast cancer MCF-7 MMP-9 and dimer secretion. Untreated breast cancer cell line MCF-7 showed neither MMP-9 nor MMP-9 dimer secretion. PMA (100 ng/ml) strongly induced MMP-9 and MMP-9 dimer, as shown in Fig. 1. NM inhibited the secretion of both in a dose-dependent manner with total block of MMP-9 dimer at $100 \mu \mathrm{g} / \mathrm{ml}$ (linear trend $\mathrm{R}^{2}=0.559$ ) and MMP-9 at $500 \mu \mathrm{g} / \mathrm{ml}$ (linear trend $\mathrm{R}^{2}=0.866$ ). Secretion of MMP-9 dimer was found to be $13 \%$ that of MMP-9. 
Table I. Human cancer cell lines expressing MMP-9 and dimer without and with PMA stimulation.

\begin{tabular}{|c|c|c|c|c|}
\hline \multirow[b]{2}{*}{ Human cancer cell line } & \multicolumn{2}{|c|}{ MMP-9 expression } & \multicolumn{2}{|c|}{ Dimer formation } \\
\hline & Without PMA & With PMA & Without PMA & With PMA \\
\hline \multicolumn{5}{|l|}{ Breast cancer } \\
\hline MDA-MB-231 & - & + & - & ++ \\
\hline MCF-7 & - & + & - & ++ \\
\hline Colo-824 & + & ++ & + & ++ \\
\hline \multicolumn{5}{|l|}{ Cervical cancer } \\
\hline HeLa & - & ++ & - & ++ \\
\hline DoTc 24510 & + & ++ & + & ++ \\
\hline \multicolumn{5}{|l|}{ Uterine cancer } \\
\hline SK-UT-1 & - & ++ & - & ++ \\
\hline MES-SA & - & + & - & - \\
\hline MES-SA/DX5 & - & + & - & - \\
\hline \multicolumn{5}{|l|}{ Prostate cancer } \\
\hline Du-145 & - & + & - & - \\
\hline PC-3 & + & + & - & - \\
\hline \multicolumn{5}{|l|}{ Testicular } \\
\hline NTER-2 & - & + & - & - \\
\hline \multicolumn{5}{|l|}{ Lung and mesothelioma } \\
\hline Lung A-549 & - & + & - & + \\
\hline MSTO-211H & + & ++ & - & - \\
\hline \multicolumn{5}{|l|}{ Gastrointestinal } \\
\hline SK-Hep-1 (HCC) & + & ++ & + & ++ \\
\hline HepG2 (HCC) & - & + & - & - \\
\hline M1A-Pa-Ca-2 (pancreas) & + & ++ & - & - \\
\hline HCT-116 (colon) & + & $-?$ & - & - \\
\hline \multicolumn{5}{|l|}{ Urological } \\
\hline T-24 (bladder) & - & + & - & - \\
\hline RCC 786-0 (renal) & + & ++ & + & ++ \\
\hline \multicolumn{5}{|l|}{ Head and neck } \\
\hline $\mathrm{FaDu}$ & - & ++ & - & - \\
\hline Tongue & + & ++ & - & ++ \\
\hline FAHNSCC (OHSU-973) & + & ++ & - & - \\
\hline \multicolumn{5}{|l|}{ Glioblastoma } \\
\hline A-172 & - & + & - & - \\
\hline T-98 & - & + & - & - \\
\hline LN-18 & - & + & - & - \\
\hline Neuroblastoma & - & + & - & - \\
\hline \multicolumn{5}{|l|}{ Sarcomas-Pediatric } \\
\hline Osteosarcoma MNNG-HOS & - & + & - & - \\
\hline SK-ES-1 & - & + & - & - \\
\hline Rhabdomhyosarcoma & + & ++ & - & ++ \\
\hline Osteosarcoma U-2OS & + & + & - & ++ \\
\hline \multicolumn{5}{|l|}{ Sarcomas-Adult } \\
\hline HT-1080 & + & ++ & - & ++ \\
\hline Chondrosarcoma & + & ++ & - & ++ \\
\hline Liposarcoma & + & ++ & - & ++ \\
\hline Synovial sarcoma & + & ++ & - & - \\
\hline \multicolumn{5}{|l|}{ Hematological } \\
\hline HL-60 & - & + & - & - \\
\hline Jurkat & - & + & - & - \\
\hline Raji & + & ++ & - & - \\
\hline \multicolumn{5}{|l|}{ Melanoma } \\
\hline A-2058 & - & ++ & - & ++ \\
\hline
\end{tabular}



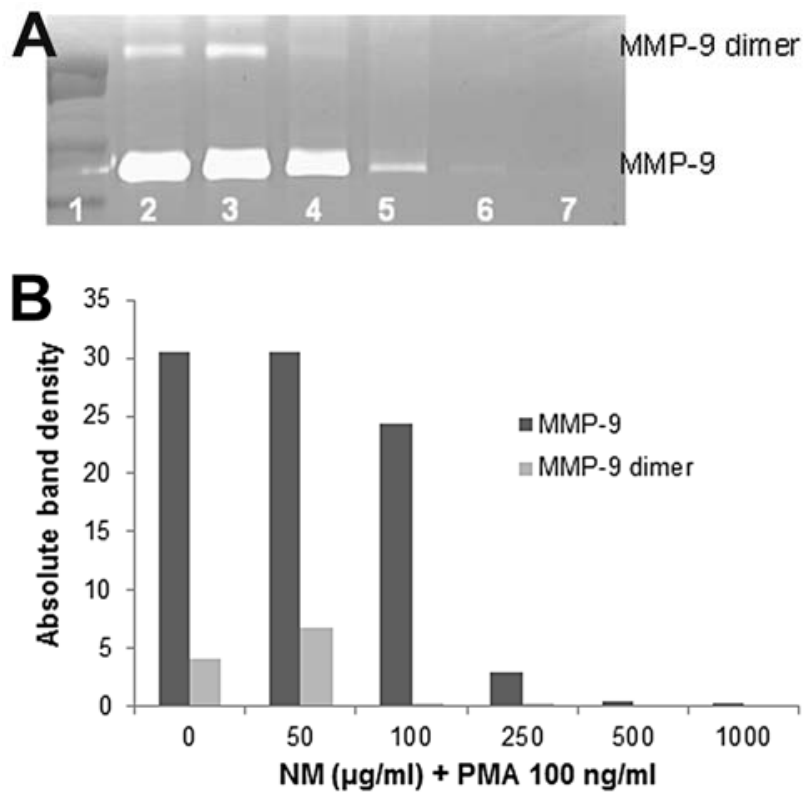

Figure 1. Effect of NM on PMA-treated breast cancer MCF-7 cell MMP-9 and MMP-9 dimer secretion. Gelatinase zymogram (A) and densitometry analysis (B); Lanes: 1, Markers; 2, Control (100 ng/ml PMA); 3-7, 100 ng/ml PMA and 10, 50, 100, 500, $1000 \mu \mathrm{g} / \mathrm{ml} \mathrm{NM}$.
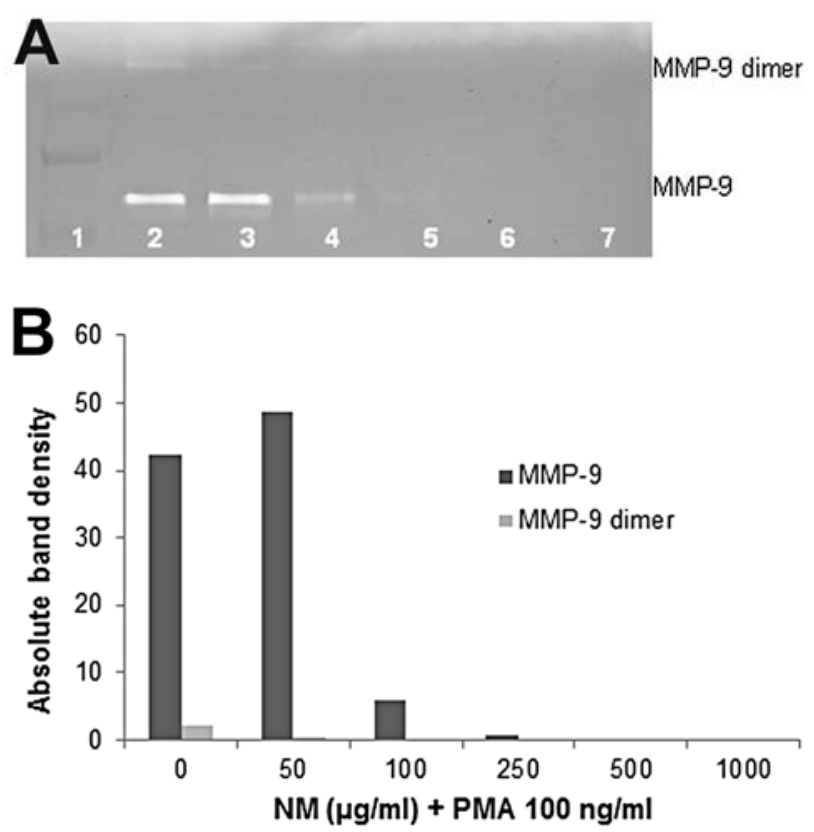

Figure 2. Effect of NM on PMA-treated lung cancer A-549 cell MMP-9 and MMP-9 dimer secretion. Gelatinase zymogram (A) and densitometry analysis (B); Lanes: 1, Markers; 2, Control (100 ng/ml PMA); 3-7, 100 ng/ml PMA and 10, 50, 100, 500, $1000 \mu \mathrm{g} / \mathrm{ml} \mathrm{NM}$.

Lung cancer A-549 MMP-9 and dimer secretion. Untreated lung cancer cell line A-549 showed neither MMP-9 nor MMP-9 dimer secretion. PMA (100 ng/ml) strongly induced MMP-9 and MMP-9 dimer, as shown in Fig. 2. NM inhibited the secretion of both in a dose-dependent manner with total block of MMP-9 dimer at $100 \mu \mathrm{g} / \mathrm{ml}$ (linear trend $\mathrm{R}^{2}=0.560$ ) and MMP-9 at $500 \mu \mathrm{g} / \mathrm{ml}$ (linear trend $\mathrm{R}^{2}=0.722$ ). Secretion of MMP-9 dimer was found to be 5\% that of MMP-9.
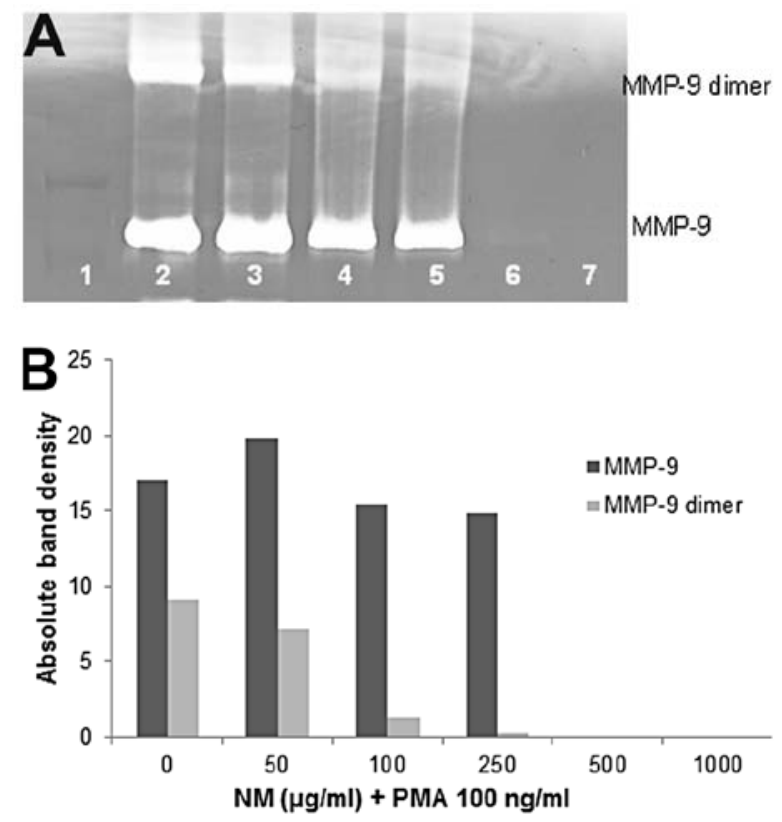

Figure 3. Effect of NM on PMA-treated osteosarcoma U-2OS cell MMP-9 and MMP-9 dimer secretion. Gelatinase zymogram (A) and densitometry analysis (B); Lanes: 1, Markers; 2, Control (100 ng/ml PMA); 3-7, 100 ng/ml PMA and 10, 50, 100, 500, $1000 \mu \mathrm{g} / \mathrm{ml} \mathrm{NM.}$

Osteosarcoma U-2OS MMP-9 and dimer secretion. Untreated osteosarcoma cell line U-2OS showed slight MMP-9 and no MMP-9 dimer secretion. PMA (100 ng/ml) strongly induced MMP-9 and MMP-9 dimer, as shown in Fig. 3. NM inhibited the secretion of both in a dose-dependent manner with total block of MMP-9 dimer at $500 \mu \mathrm{g} / \mathrm{ml}$ (linear trend $\mathrm{R}^{2}=0.780$ ) and MMP-9 at $500 \mu \mathrm{g} / \mathrm{ml}$ (linear trend $\mathrm{R}^{2}=0.768$ ). Secretion of MMP-9 dimer was found to be 54\% that of MMP-9.

Chondrosarcoma SW-1353 MMP-9 and dimer secretion. Untreated chondrosarcoma cell line SW-1353 showed moderate MMP-9 and no MMP-9 dimer secretion. PMA (100 ng/ml) strongly induced MMP-9 and MMP-9 dimer, as shown in Fig. 4. NM inhibited the secretion of both in a dose-dependent manner with total block of MMP-9 dimer at $250 \mu \mathrm{g} / \mathrm{ml}$ (linear trend $\mathrm{R}^{2}=0.843$ ) and MMP-9 at $500 \mu \mathrm{g} / \mathrm{ml}$ (linear trend $\mathrm{R}^{2}=0.729$ ). Secretion of MMP-9 dimer was found to be $25 \%$ that of MMP-9.

Dimer secretion with and without PMA. Cervical DoTc 24510 , renal 786-0, breast Colo-824 and HCC SK-Hep-1 exhibited MMP-9 dimer secretion without PMA treatment and increased secretion with PMA treatment. See Table I for relative secretion of MMP-9 monomer and dimer. Zymograms and densitometry analyses of secretion patterns of MMP-9 monomer and dimer of representative cancer cell lines cervical DoTc 2 4510, hepatocellular carcinoma Sk-Hep-1 and leiomyosarcoma SK-UT-1 are presented below.

Cervical cancer DoTc 24510 MMP-9 and dimer secretion. Untreated cervical cancer cell line DoTc 24510 showed MMP-9 and MMP-9 dimer secretion which was strongly induced with PMA (100 ng/ml), as shown in Fig. 5. NM inhibited the secretion of both in a dose-dependent manner with total 

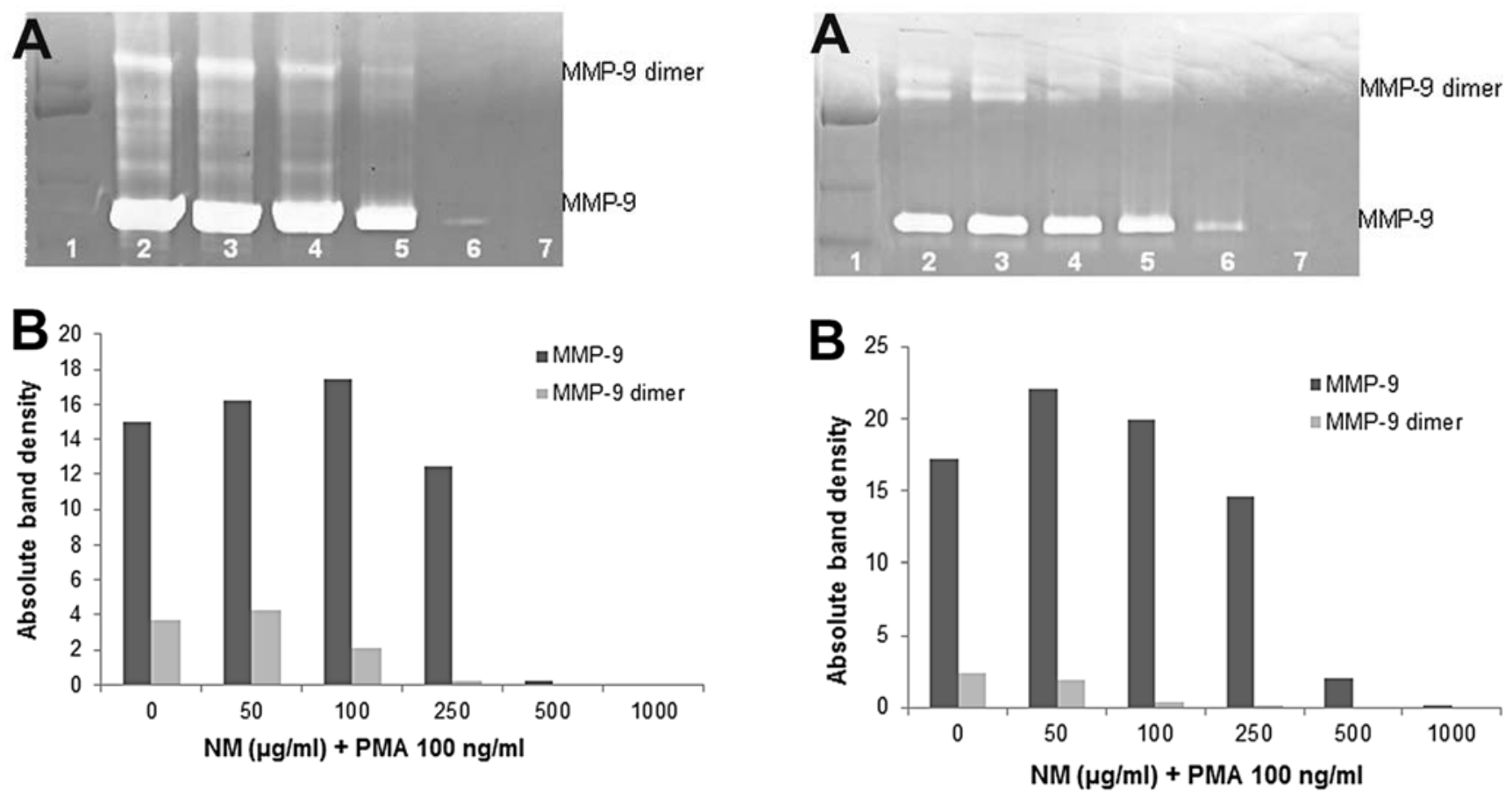

Figure 4. Effect of NM on PMA-treated chondrosarcoma SW-1353 cell MMP-9 and MMP-9 dimer secretion. Gelatinase zymogram (A) and densitometry analysis (B); Lanes: 1, Markers; 2, Control (100 ng/ml PMA); 3-7, $100 \mathrm{ng} / \mathrm{ml} \mathrm{PMA}$ and $10,50,100,500,1000 \mu \mathrm{g} / \mathrm{ml} \mathrm{NM}$.
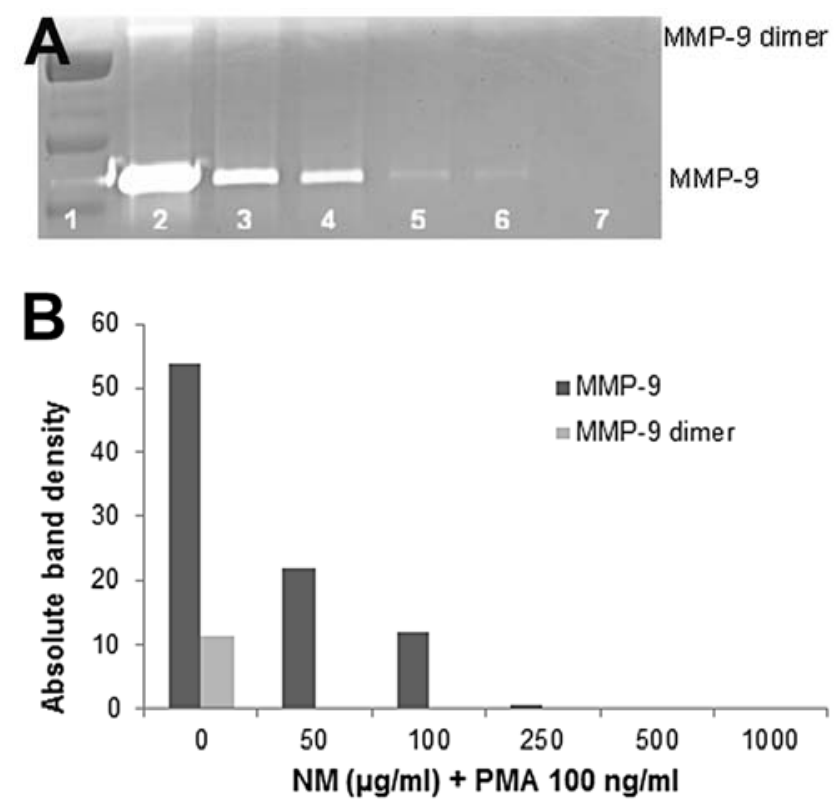

Figure 5. Effect of NM on PMA-treated cervical cancer DoTc 24510 cell MMP-9 and MMP-9 dimer secretion. Gelatinase zymogram (A) and densitometry analysis (B); Lanes: 1, Markers; 2, Control (100 ng/ml PMA); 3-7, $100 \mathrm{ng} / \mathrm{ml}$ PMA and 10, 50, 100, 500, $1000 \mu \mathrm{g} / \mathrm{ml} \mathrm{NM}$.

block of MMP-9 dimer at $50 \mu \mathrm{g} / \mathrm{ml}$ (linear trend $\mathrm{R}^{2}=0.429$ ) and MMP-9 at $500 \mu \mathrm{g} / \mathrm{ml}$ (linear trend $\mathrm{R}^{2}=0.769$ ). Secretion of MMP-9 dimer was found to be $21 \%$ that of MMP-9.

Hepatocellular carcinoma SK-Hep-1 MMP-9 and dimer secretion. Untreated and PMA $(100 \mathrm{ng} / \mathrm{ml})$-treated hepatocellular carcinoma cell line SK-Hep-1 showed both MMP-9 and

Figure 6. Effect of NM on PMA-treated hepatocellular carcinoma SK-Hep-1 cell MMP-9 and MMP-9 dimer secretion. Gelatinase zymogram (A) and densitometry analysis (B); Lanes: 1, Markers; 2, Control (100 ng/ml PMA); $3-7,100 \mathrm{ng} / \mathrm{ml}$ PMA and 10, 50, 100, 500, $1000 \mu \mathrm{g} / \mathrm{ml} \mathrm{NM}$.
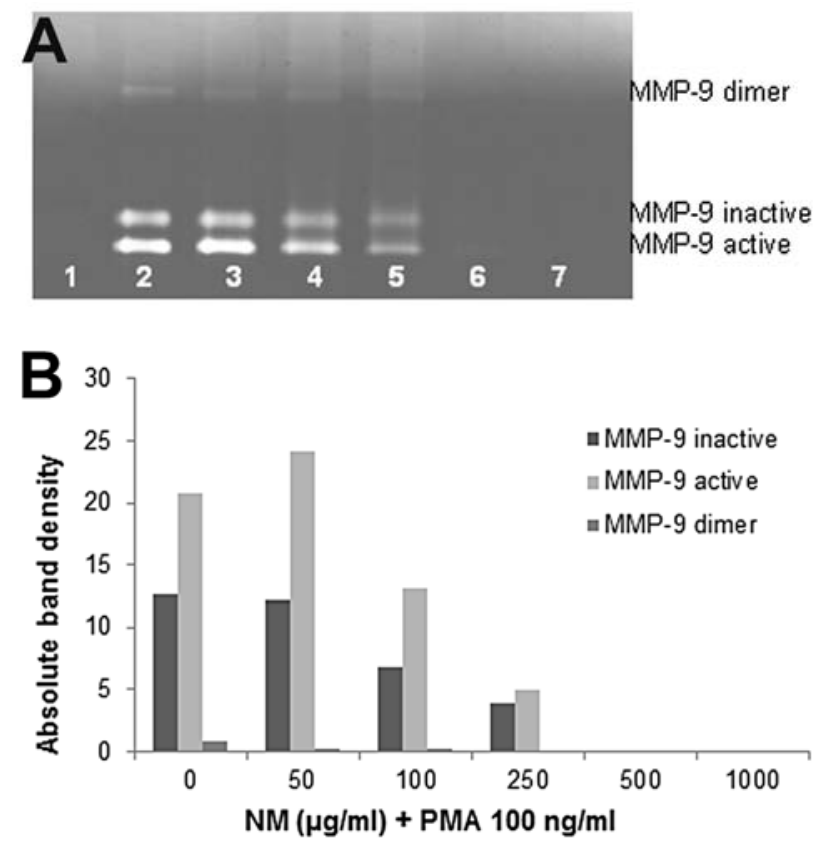

Figure 7. Effect of NM on PMA-treated uterine leiomyosarcoma SK-UT-1 cell MMP-9 and MMP-9 dimer secretion. Gelatinase zymogram (A) and densitometry analysis (B); Lanes: 1, Markers; 2, Control (100 ng/ml PMA); 3-7, $100 \mathrm{ng} / \mathrm{ml}$ PMA and 10, 50, 100, 500, $1000 \mu \mathrm{g} / \mathrm{ml} \mathrm{NM}$.

MMP-9 dimer secretion. NM inhibited the secretion of both in a dose-dependent manner with total block of MMP-9 dimer at $250 \mu \mathrm{g} / \mathrm{ml}$ (linear trend $\mathrm{R}^{2}=0.824$ ) and MMP-9 at $1000 \mu \mathrm{g} / \mathrm{ml}$ (linear trend $\mathrm{R}^{2}=0.746$ ), as shown in Fig. 6. Secretion of MMP-9 dimer was found to be $14 \%$ that of MMP-9. 
Uterine leiomyosarcoma SK-UT-1 MMP-9 and dimer secretion. PMA (100 ng/ml)-treated leiomyosarcoma cell line SK-UT-1 showed both MMP-9 and MMP-9 dimer secretion. NM inhibited the secretion of both in a dose-dependent manner with total block of MMP-9 dimer at $250 \mu \mathrm{g} / \mathrm{ml}$ (linear trend $\mathrm{R}^{2}=0.713$ ) and MMP-9 active and inactive at $500 \mu \mathrm{g} / \mathrm{ml}$ (linear trend $\mathrm{R}^{2}=0.884$ and 0.994 , respectively), as shown in Fig. 7. Secretion of MMP-9 dimer was found to be $4 \%$ that of MMP-9 active.

\section{Discussion}

Tumor cell invasion requires the critical steps of cell attachment, degradation of the ECM and migration through the disrupted matrix. Matrix metalloproteinases, especially MMP-2 and MMP-9, play pivotal roles in tumor cell invasion and metastasis due to their ability to degrade type IV collagen, a major component of the ECM. In our study, MMP-9 dimer secretion patterns of cancer cells fell into different categories. We observed no MMP-9 dimer in prostate DU-145 and PC-3, pancreatic MIA-Pa-Ca2, colon HCT-116, bladder T-24, head and neck FaDu, glioblastoma A-172, T-98 and LN-18 and leukemia HL-60, Jurkat, and Raji cell lines. MMP-dimer secretion only with PMA induction was seen in breast MCF-7 and MDA-MB-231, uterine SK-UT-1, lung A-549, tongue SC-25, melanoma A2058, osteosarcoma U-2OS, rhabdomyosarcoma, fibrosarcoma HT-1080, chondrosarcoma SW-1350 and liposarcoma SW-872.

Cervical HeLa and DoTc 2 4510, renal 786-0 and HCC SK-Hep-1 exhibited MMP-9 dimer without PMA treatment and increased secretion with PMA treatment. Sarcomas had the highest levels of MMP-9 monomer and dimer combined with and without PMA among these cancer cell lines. In addition, osteosarcoma showed the highest MMP-9 dimer to MMP-9 ratio, indicating a very aggressive cancer. Cervical, uterine, and male breast cancer cell lines showed the next highest levels of combined MMP-9, followed by breast cancer cell lines. Melanoma, renal, lung, head and neck and HCC showed lower levels and prostate, glioblastoma, bladder and leukemia cell lines the lowest. The NM showed dose-dependent inhibition of MMP-9 monomer and dimer in all cell lines tested.

In contrast to the associated toxicity and limited efficacy of standard cancer chemotherapy and radiation therapy, the efficacy and safety of dietary and botanical natural compounds in cancer prevention has been extensively documented (11). The critical aspect in cancer invasion, metastasis and angiogenesis is stability and integrity of connective tissue which is compromised by its excessive enzymatic digestion (MMPs and uPA) and insufficient production due to deficiency of critical nutrients in cancer patients $(5,6,10)$. Therefore, our nutrient mixture was formulated by selecting nutrients that act on critical physiological targets in cancer progression and metastasis, as documented in both clinical and experimental studies.

Optimal ECM structure depends upon adequate supplies of ascorbic acid and the amino acids lysine and proline to ensure proper synthesis and hydroxylation of collagen fibers. In addition, lysine contributes to ECM stability as a natural inhibitor of plasmin-induced proteolysis $(9,13)$. Manganese and copper are also essential for collagen formation. There is considerable documentation of the potency of green tea extract in modulating cancer cell growth, metastasis, angiogenesis, and other aspects of cancer progression (14-20). N-acetyl cysteine and selenium have demonstrated inhibition of tumor cell MMP-9 and invasive activities, as well as migration of endothelial cells through ECM (21-23). Ascorbic acid demonstrates cytotoxic and antimetastatic actions on malignant cell lines (24-29) and cancer patients have been found to have low levels of ascorbic acid (30,31). Low levels of arginine, a precursor of nitric oxide (NO), can limit the production of $\mathrm{NO}$, which has been shown to predominantly act as an inducer of apoptosis (32).

In conclusion, high MMP-9 and dimer secretion levels correlated with the most aggressive cancer cell lines. NM was effective in inhibiting MMP-9 and dimer secretion in all cell lines tested, suggesting its therapeutic potential as an antimetastatic agent.

\section{Acknowledgements}

This study was funded by Dr. Rath Health Foundation (Santa Clara, CA, USA), a non-profit organization. Mr. Monterrey provided assistance in scanning the gels.

\section{References}

1. Kleiner DL and Stetler-Stevenson WG: Matrix metalloproteinases and metastasis. Cancer Chemother Pharmacol 43 (Suppl): S42-S51, 1999.

2. Yurchenko PD and Schitny JC: Molecular architecture of basement membranes. FASEB J 4: 1577-1590, 1990.

3. Barsky SH, Siegel GP, Jannotta F and Liotta LA: Loss of basement membrane components by invasive tumors but not by their benign counterparts. Lab Invest 49: 140-147, 1983.

4. Liotta LA, Tryggvason K, Garbisa A, Hart I, Foltz CM and Shafie S: Metastatic potential correlates with enzymatic degradation of basement membrane collagen. Nature 284: 67-68, 1980.

5. Stetler-Stevenson WG: The role of matrix metalloproteinases in tumor invasion, metastasis and angiogenesis. Surg Oncol Clin N Am 10: 383-392, 2001.

6. Stetler-Stevenson WG: Type IV collagenases in tumor invasion and metastasis. Cancer Metastasis Rev 9: 289-303, 1990.

7. Dufour A, Zucker S, Sampson NS, Kuscu C and Cao J: Role of matrix metalloproteinase-9 dimers in cell migration: design of inhibitory pepides. J Biol Chem 285: 35944-35956, 2010.

8. Bjorland $\mathbf{M}$ and Koivunen E: Gelatinase-mediated migration and invasion of cancer cells. Biochim Biophys Acta 1755: 37-69, 2005.

9. Rath M and Pauling L: Plasmin-induced proteolysis and the role of apoprotein(a), lysine and synthetic analogs. J Orthomol Med 7: 17-23, 1992.

10. Andreasen PA, Kjøller L, Christensen L and Duffy MJ: The urokinase-type plasminogen activator system in cancer metastasis: a review. Int J Cancer 72: 1-22, 1997.

11. Niedzwiecki A, Roomi MW, Kalinovsky $\mathrm{T}$ and Rath M: Micronutrient synergy - a new tool in effective control of metastasis and other key mechanisms of cancer. Cancer Metastasis Rev 29: 529-543, 2010.

12. Amin ARMR, Kucek O, Khuri FR and Shin DM: Perspectives for cancer prevention with natural compounds. J Clin Oncol 27: 2712-2725, 2009

13. Sun Z, Chen YH, Wang P, Zhang J, Gurewich V, Zhang P and Liu JN: The blockage of high-affinity lysine binding sites of plasminogen by EACA significantly inhibits prourokinase-induced plasminogen activation. Biochem Biophys Acta 1596: 182-192, 2002.

14. Kemberling JK, Hampton JA, Keck RW, Gomez MA and Selman SH: Inhibition of bladder tumor growth by the green tea derivative epigallocatechin-3-gallate. J Urol 170: 773-776, 2003.

15. Sato D and Matsushima M: Preventive effects of urinary bladder tumors induced by N-butyl-N-(4-hydroxybutyl)-nitrosamine in rat by green tea leaves. Int J Urol 10: 160-166, 2003. 
16. Valcic S, Timmermann BN, Alberts DS, Wachter GA Krutzsch M, Wymer J and Guillen JM: Inhibitory effect of six green tea catechins and caffeine on the growth of four selected human tumor cell lines. Anticancer Drugs 7: 461-468, 1996.

17. Mukhtar H and Ahmed N: Tea polyphenols: prevention of cancer and optimizing health. Am J Clin Nutr 71 (Suppl 6): S1698-S1704, 2000.

18. Yang GY, Liao J, Kim K, Yurtow EJ and Yang CS: Inhibition of growth and induction of apoptosis in human cancer cell lines by tea polyphenols. Carcinogenesis 19: 611-616 1998

19. Taniguchi S, Fujiki H, Kobayashi H, Go H, Miyado K, Sadano H and Shimikawa R: Effect of (-) epigallocatechin gallate, the main constituent of green tea, on lung metastasis with mouse B16 melanoma cell lines. Cancer Lett 65: 51-54, 1992.

20. Hara Y: Green Tea: Health Benefits and Applications. Marcel Dekker. New York, Basel, 2001.

21. Kawakami S, Kageyama Y, Fujii Y, Kihara K and Oshima H: Inhibitory effects of $\mathrm{N}$-acetyl cysteine on invasion and MMP 9 production of T24 human bladder cancer cells. Anticancer Res 21: 213-219, 2001.

22. Morini M, Cai T, Aluigi MG, Noonan DM, Masiello L, De Floro S, D'Agostinin F, Albini A and Fassima G: The role of the thiol $\mathrm{N}$-acetyl cysteine in the prevention of tumor invasion and angiogenesis. Int J Biol Markers 14: 268-271, 1999.

23. Yoon SO, Kim MM and Chung AS: Inhibitory effects of selenite on invasion of HT 1080 tumor cells. J Biol Chem 276: 20085-20092, 2001

24. Naidu KA, Karl RC and Coppola D: Antiproliferative and proapoptotic effect of ascorbyl stearate in human pancreatic cancer cells: association with decreased expression of insulinlike growth factor 1 receptor. Dig Dis Sci 48: 230-237, 2003.
25. Anthony HM and Schorah CJ: Severe hypovitaminosis $\mathrm{C}$ in lungcancer patients: The utilization of vitamin $C$ in surgical repair and lymphocyte-related host resistance. Br J Cancer 46: 354-367, 1982.

26. Maramag C, Menon M, Balaji KC, Reddy PG and Laxmanan S: Effect of vitamin $C$ on prostate cancer cells in vitro: effect on cell number, viability and DNA synthesis. Prostate 32: 188-195, 1997.

27. Koh WS, Lee SJ, Lee H, Park C, Park MH, Kim WS, Yoon SS, Park K, Hong SI, Chung MH and Park CH: Differential effects and transport kinetics of ascorbate derivatives in leukemic cell lines. Anticancer Res 8: 2487-2493, 1998.

28. Chen Q, Espey MG, Krishna MC, Mitchell JB, Corpe CP, Buettner GR, Shacter E and Levine M: Pharmacologic ascorbic acid concentrations selectively kill cancer cells: Action as a pro-drug to deliver hydrogen peroxide to tissues. Proc Natl Acad Sci USA 102: 13604-13609, 2005.

29. Harakeh S, Diab-Assaf M, Khalife JC, Abu-el-Ardat KA, Baydoun E, Niedzwiecki A,El-Sabban ME and Rath M: Ascorbic acid induces apoptosis in adult T-cell leukemia. Anticancer Res 27: 289-298, 2007.

30. Núñez Martín C and Ortiz de Apodaca y Ruiz A: Ascorbic acid in the plasma and blood cells of women with breast cancer. The effect of consumption of food with an elevated content of this vitamin. Nutr Hosp 10: 368-372, 1995 (In Spanish).

31. Kurbacher CM, Wagner U, Kolster B, Andreotti PE, Krebs D and Bruckner HW: Ascorbic acid (vitamin C) improves the antineoplastic activity of doxorubicin, cisplatin and paclitaxel in human breast carcinoma cells in vitro. Cancer Lett 103: 183-189, 1996.

32. Cooke JP and Dzau VJ: Nitric oxide synthase: role in the genesis of vascular disease. Annu Rev Med 48: 489-509, 1997. 